\title{
INVENTORY AND CHOICE IN EXPRESSIVE LANGUAGE
}

\author{
WILLIAM J. SAMARIN
}

\section{INTRODUCTION}

In this paper I should like to suggest that one of the characteristics of the expressive use of language is the utilization of a set of words different in each language but manifesting in all languages certain phonologic and semantic similarities.

By the term EXPRESSIVE USE OF LANGUAGE I do not mean anything more than the manipulation of verbal material to convey information about one's emotional state. ${ }^{1}$ The assumption is made that the purely referential function of language in at least some ways is distinguishable from its expressive function; that, for example, the words cat, dog, or pig can be used in the English-speaking world to refer both to certain kinds of animals and also to people at certain times, namely, when we react to them under certain conditions. In other words, the sentence You're a pig! may tell us more about the state of the speaker than about the person spoken to.

That expressive language is also characterized by the selection of prosodic as well as paralinguistic material is not ignored. Thus, in the sentence just cited one would expect a certain intonational contour from among the many which the speaker of English has at his disposal. There would be stress on the word pig. But pig would probably also be pronounced with a long or extra-long vowel, and the initial consonant might be articulated with extreme aspiration or be replaced by a bilabial affricate [pf] or even a voiceless bilabial trill. At this point the word pig is hardly more than a means to express disgust, very much akin to the interjection brrr (with either the central retroflexed vocoid or a voiced bilabial trill) in Brr, I'm cold.

Interjections and exclamations, of course, are at one end of the scale if one were to rank words in a language. They are primarily expressive and are also, for other reasons, marginal to what is generally called 
linguistic structure. Elsewhere in language, lexicon figures expressively only by the selection made by a speaker. For example, in talking otherwise formally to a person many years my junior I can give expression - as indeed I did - to the fact that in my opinion he was not taking his work very seriously, by the simple device of choosing bucks for dollars. The word buck is therefore not simply a slang equivalent of dollar, as we are informed in Webster's third international dictionary. On this occasion it might have meant 'a dollar which is not properly valued', but the point is that the speaker avoided dollar because of his emotional state at the time of speech, not merely because slang was more appropriate.

What can we say about selection in expressive speech? Are there some universal traits or must expressive language always be defined for each speech community? Can it be demonstrated, for example, that linguistic forms most characteristic of expressive language contain certain phonemes, or display more reduplication than is otherwise present in the language, or are generally associated with a restricted set of semantic areas? We need to also ask how languages differ in the material they provide the speakers. Do some languages have classes of words - perhaps coordinate with those that might be called nouns or verbs or perhaps subclasses (on purely linguistic grounds) - which have a peculiar function in linguistic behavior? These are some questions which ought to be faced in the study of expressive language.

Up until now discussions about expressive speech have been almost exclusively in connection with languages of the West, with literature, with particular genres of verbal art, and with what is generally called style. We know little about this subject for spoken languages of civilization and less about languages in preliterate societies.

\section{IDEOPHONIC WORDS THROUGHOUT THE WORLD}

Here then, first of all, is a list of languages in which are found words which, despite the non-relatedness of the languages themselves, reveal certain phonologic and semantic similarities. For some, their expressive function is known or strongly suggested; for others we can only assume it.

For the sake of convenience I shall call these words 'ideophonic', using an adjectival form of the noun that $C$. M. Doke coined to denominate a class of words in the Zulu language. ${ }^{2}$ When he applied the term to the study of Bantu languages in general, he defined it as follows: An 
ideophone is a "word, often onomatopoeic, which describes a predicate, qualificative or adverb in respect to manner, colour, sound, smell, action, state or intensity" (1935:118). ${ }^{3}$ Notice that the definition is partly linguistic, when he refers to their place in syntax, for example, and partly semantic, as when he specifies their range of meaning. This is true of so many names by which they have been known: e.g. 'descriptive radical', 'descriptive adverb', 'intensive interjection', 'interjectional adverb', 'mimic noun', 'onomatopoeic adverb', 'phonesthetic particle', 'word picture', etc.

We make no brief for Doke's choice of a term, of course. What maintains our attention is the kind of phenomena which we find in African languages and elsewhere. In Gbeya, an Adamawa-Eastern language (of Greenberg's Benue-Congo family) spoken in the Central African Republic, the ideophonic words are adverbs, but as a class they behave differently and have a semantic range which is different from the other adverbs, which are exhausted by this list: dé 'lot, much, very, hard', 6o 'also', $d \delta k a$ 'much, many' ( $<d o k$ 'to be many'), gso 'here', gõ $y$ 'in this manner', gbán 'also accompanying', and sốn 'all, entirely' (<sin 'to finish off, exterminate'). The ideophonic adverbs, on the other hand, constitute an open class. In my lexical file there are about 5,000 of them. In the Zulu-English dictionary by C. M. Doke and B. W. Vilakazi there are about 2,600 of them (Fivaz 1963). A few Gbeya ones are listed below alongside some nouns and verbs to illustrate the differences in phonemic shape. These were selected by simple taking the first word in the alphabetical listing for each category. This explains the high incidence of the letter $a$.

\section{Comparison of Gbeya Vocabularies}

Ideophones

1. bada kara

2. Gakat bakat

3. dan day

4. dáá oili

5. $\varepsilon l \varepsilon l \varepsilon$

6. fáká fáká

7. gada guda

8. gbalan gbalay

9. hada hada

10. kakada

11. kpálán

12. láázák

13. $m \tilde{\varepsilon} n$
Nouns

báa 'father's sister'

baba 'mallet'

dadákd 'wood bores'

dáymgbá 'testicle'

Éwo 'ladder'

fábé 'ashes after leaching'

gadá 'a certain fowl'

g6adá 'lizard'

$h \tilde{\varepsilon} \bar{\varepsilon} r \varepsilon$ 'a certain grass'

káká 'rust'

kpan 'a certain animal'

lában 'a certain caterpillar'

mãre 'a certain fish'
Verbs
$b a$ 'to seize'
$6 a$ 'to disavow'
dabi 'to hesitate'
6engi 'to be large'
$\varepsilon k$ 'to lean'
fãn 'to weave'
gabi 'to hold back'
$g b a$ 'to break'
$h a$ 'to give'
$k a$ 'to win in gambling'
$k p a$ 'to find'
langi 'to pass on'
$m \tilde{a}$ 'to appear from below' 
Although there are only 13 in this list, they are seen to be markedly different from the nouns and verbs. Reduplication, either complete, as in 2 , or partial, as in 10, is a common feature. Sometimes this reduplication is accompanied by changes in the vowels, as in 4 and 7 . When compared with the nouns, it is further seen that the ideophones have either all high or all low tones. (The tones of the verbs would not be comparable, because the tone changes are grammatical.)

The semantics of these ideophonic adverbs can not at this time be satisfactorily reported, for they have never been submitted to any rigorous semantic analysis. ${ }^{4}$ This is likewise true for all other African languages. One of the reasons is that these words are so difficult to define. That is, it would take more than the usual field data, as I have pointed out elsewhere (Samarin 1965), to obtain the information necessary for establishing semantic oppositions. Another reason, however, is that ideophonic words have generally been regarded with less seriousness than the rest of a language's lexicon. It has been felt that, like interjections, they did not belong to the warp and woof of language. The accompanying material, however, gives some idea of the kinds of meanings which are represented by these words. It should be noticed that only some of them are onomatopoeic.

The expressive function of these Gbeya adverbs is documented by the excerpt from a very lively description of the annual grass-burning hunts below. The excitement and sense of pleasure in the vicarious participation in this hunt can not, of course, be represented by any system of notation. It is the adverbs themselves which perform this function: take them out, and the narration becomes as tasteless as oatmeal without salt; we would know what went on in a hunt, but it would no longer be exciting.

\section{Excerpt from a Gbeya Text Describing Annual Grass-Burning}

nd $\varepsilon$ wa bá dalí ñ̃ dứn wa mbéć nde wa bá đon-ré nde wa lángí dứn wa nế sẽné nde wa sá gĩma go wa bá gìma'-ngan wí go dứn wa sá gĩma fu, fu, fu fu

dū wa $n \varepsilon \tilde{\varepsilon} n \hat{\varepsilon}$, g $\varepsilon \dot{\varepsilon}-$-wa dứn wéé nmgbodjk, ymgbon gmgbo and they take the dal drum and they begin to beat it and they leave the village and they go on they continue and they sing and they take up the ngan wi song and they begin to sing *(unintelligible distant voices)

they go on like this, their voices sound *(low and undulating) 
wí-ré zéé géé-wa ...

nz̃ wãn-gbíya a bá geze é nũ

gã ã gbó zúa gundư

gã ã dé nế kam há ó ngaragé ká ã go ỹ̃n ...

gó wey bó mร̃y t $\varepsilon^{\prime}$-sãna

go bó 6o kokoron kor

gende gá wãn-gbiya zoká

gende gá rễmà mấa ai gĩ gam guram ãi

$n \tilde{\varepsilon}$ bcn $n \tilde{\varepsilon}$ kote wí-pĩ gam guramí a bá kóa tí

gã ã pĩ hốốó

Gวิ́n nã ã ró $n \varepsilon$ nmã gấsắ te vọ, $\mathrm{a}$ mbán ...

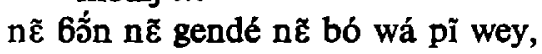
e wey $s \varepsilon \tilde{n}-t \varepsilon \varepsilon^{\prime} b 3 ̃$ ńa vip

bǻ ấ gõm tut

ñ 6วิ́n ñ̃ wey bó kpa ymãá gbongom bõn5́a

nẽ gam guram bó zũ nũ Bũy

géć-gam guram dũy wéé gbi gbi gbi, gbii gbii, gbíi gbí

gende gá ó wí-ñ̃ yarí bó zee géćgam guram bó dũn nõy diriri diriri goy

gende gá ó wí-yari kelà kálá kẻlá

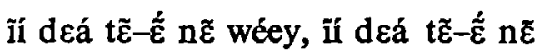
wéey

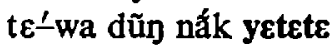

dũy wa gbóđí sére mṍ sem sem, SEm sEm

dứn wa háy đoớwey nóo mố gẽrøฺ, gẽ̃ren gž ren ... people hear their voices ...

and the master of the grass area takes a basket of his sesame and puts it on the ground

and he breaks [the dry, grass-covered] top *open paw!

and he makes food out of it for his hunters, and they eat ...

and when the fire meets in the middle

and when it circles *around in a circular manner

in other words the master of the grass has seen

that it is time for him to throw in the whirlwind

and right then the thrower of the whirlwind takes the female one [of the magical nut shells] first

and he throws it *swiftly

like that and it hits a large tree *with a bang, and splits ...

just like that and in other words when they cast in the fire, er, set fire behind *forcefully

when he draws [the firebrand] away *suddenly and just like that when the fire meets *boom behind

and when the whirlwind descends to the ground *wham!

the whirlwind's voice begins to go *(making a roaring sound)

in other words when the hunters hear the voice of the whirlwind beginning to boil *(with the sound whii whii) like this

in other words the hunters are happy *extremely

that one makes himself into a man, that one makes himself into a man

their bodies begin to tremble *(in a trembling manner)

they make (their) spears tremble *(in a trembling manner)

they begin to creep up behind this fire *very rapidly ...

This is based on a recording presented in another form as Text 10 in Samarin 1966. The phonology has since then been re-analyzed. It turns out that the implosive stops $b$ and $d$, as well as the prenasalized stops $m b, n d, \eta g$, and $\eta m g b$ occur only before oral vowels and their counterparts; preglottalized nasals on the one hand and the nasal continuants on the other, occur elsewhere. The latter generalization means that $m$, $n, \eta$, and $\eta m$ (a coarticulated bilabial-velar nasal) occur (1) before nasalized vowels but (2) following oral vowels only when in final position - with the exception of $\eta m$ that never occurs finally. In this transcription, however, the phonetic difference between the nasal continuants and the prenasalized stops is maintained. Ideophones are in boldface and their translations are marked by an asterisk. 
I have used Gbeya because I know it best, but ideophonic words are typical of Sub-Saharan Africa as a linguistic area. No typologizing of African languages will be complete without a recognition of them. ${ }^{5}$ Genetic relationship is no determining factor, for Congo-Kordofanian, Nilo-Saharan, and even Afroasiatic - all still considered unrelated by Greenberg and others - are characterized by ideophonic words. (The Khoisan languages do not appear to have such words. This opinion is based on an examination of the literature and is confirmed by specialists.) Afroasiatic, which includes Semitic, Berber, and Cushitic, occurs, it must be remembered, in very 'Africanized' forms in the Chad family, exemplified by Hausa.

This process of 'Africanization' is seen also in the creoles based on European languages: English - Sierra Leone Krio, West African Pidgin, Gullah, Jamaican, Saramacan, Sranan; Portuguese - Crioulo; French Haitian. ${ }^{6}$ What is borrowed (i.e. from African languages) in these languages is not only stimulus for a specialized class of words with a particular use but also a model for their phonological realization. It is said of the Crioulo ones, for example: "While the use of such particles is a West African feature, the ones used in $\mathrm{Cr}$ [Crioulo] are assumed to be of $\mathrm{Cr}$ origin, since they are not relatable to those in other languages. Many are of CVC pattern, and have final consonants not otherwise met in this position in $\mathrm{Cr}$; they further are liable to phonetic and pitch variations which are not generally possible" (Wilson 1962:34). Wilson feels that the Crioulo use of ideophones is for emphasis (probably because they accompany certain adjectives and are not interchangeable, a feature which I found to be characteristic of Wolof) whereas in Krio the use is "to give greater vividness to actions in narrative" (35).

In many languages (as in Gbeya) the ideophonic words are adverbs; in Ijo they are described as a particular class of stative verbs (Williamson 1965), in Igbo as a particular class of nouns (Green and Igwe 1963); some languages derive them from other word classes, or they can go into other classes (the direction is not always easy to determine); in some they have a great freedom of occurrence, and in others they seem to be related to specific verbs.

Elsewhere in the world, but never in as extensive an area as on the African continent, we find similar classes of words. What is striking about them, as with African ideophonic words, is that (1) they display a great deal of play with sounds, that (2) they are predominantly reduplicative, that (3) their phonology is in some respects different from that of all other words, and finally, that (4) they have very specific 
meanings sometimes difficult to define. Published reports about these words have little to say about their expressive use, for they have been descriptive studies which, as we all know, convey precious little information about human behavior which accompanies speech. ${ }^{7}$

Korean, according to Martin, has about 1000 words which he calls "impressionistic (or mimetic) adverbs" whose reference is to the subjective impression of sounds, sight, smell, taste, touch, and non-specific reaction. E.g. $k$ kol $k$ kol 'bubble-bubble', kantul 'gently swaying', potong 'chubby, plump', sswuk 'abruptly', kkak 'tight, firm, fast', kkamak 'flickering, blinking, winking', etc.

Azerbaijani shares with other Turkic languages a class of words which appears to be predominantly onomatopoeic. Householder lists 72 of them for that language. For example, pyrylty 'flutter (as of wings)', borultu 'speak in low-pitched, hoarse, strong voice'. But there are also a "very few non-onomatopes" that show similar types of formation; for example, parylty 'be bright', isylty 'be clear (of sky)', and damzylty 'drip (of water)'.

Malagasy is another language with a very extensive list of onomatopoeic words with highly differentiated referents, but there are many words like hitakitaka 'palpitation, émotion intérieure causée par l'inquiétude, la peur ou l'espérance d'un plaisir', and hirihiri 'opiniâtreté, entêtement, obstination, refus, inflexibilite' whose reference is primarily to a psychological state. Bernard-Thierry $(1961: 267)$ furthermore admits: "On voit ... que la frontière n'est pas nette, que la limite entre le bruit, le mouvement, 'l'état d'âme', manque de précision."

The similarity to African ideophonic words is also found in the socalled Mon-Khmer languages: for example, Khmu? (Smalley 1961), Brôu (Miller 1964), Bahnar (Banker 1964), Pakoh (Watson 1966), and Khasi (Rabel 1961). In Khasi there is a sub-class of adverbs which "elaborate on the action performed by the verb and are chosen with respect to size, shape, color, or manner of the grammatical subject. Their number is almost limitless because they can be made up on the spur of the moment. The proper choice of these proper adverbs determines a speaker's mastery of the language, his ability to express the finest shade of meaning, his mastery of style" (Rabel 1961:63). As with the adverbs in some African languages, a Khasi verb may have a definite set of 'satellite' adverbs that is used with it, although some

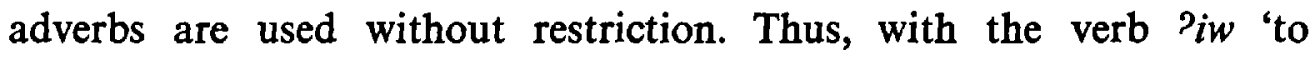
smell' can occur bii' 'have an aromatic sweet smell', jlep 'to smell of rotten fish'; the verbs pej and $k h m i$ ' which mean 'to look, see' 
take prman 'from a distance', klewklew 'glitteringly (like a peacock)', etc.

In that same part of the world Assamese (a Magadhan language of Indo-Aryan), Tamil (Arden 1954), and Thai also have words which in form and function appear to display the phenomena under consideration. ${ }^{8}$

For the Western Hemisphere we have information at this time only on Yokuts and Waiwai. The former, according to Stanley Newman (1964:375), has a "special class of verbs which, in contrast to the generalized concepts typical of the language, express notions that are narrowly defined and specific. ... From the perspective of Yokuts, these verbs are linguistic freaks. Their grammatical form, as well as their content, is anomalous in the Yokuts system. These verbs are composed of two elements, a stem of the verb wiyi 'do, do thus', being added to another stem defining the nature of the activity." For this reason they are called 'do' verbs. Some of them are mimetic, like ga:gwiyi 'to cackle', but others are not, for example, bidinwiyi 'to tumble from a high place', and no:mno:mwiyi 'to make puckering motions in and out'. Of Waiwai, spoken in British Guiana, we know only that Nida equates a certain class of words with African ideophones, saying that they are used with great frequency, and "without them one can scarcely communicate the emotional tone of [a] message, for they provide the basic signals for understanding the speaker's attitude toward the events he narrates" (1964: 169).

\section{DIAGNOSTIC GUIDE TO EXPRESSIVE PHENOMENA}

We are undoubtedly far from thoroughly listing the languages which have more or less well-developed expressive vocabularies. ${ }^{9}$ Perhaps we could find better ways, in fact, of approaching this particular psycholinguistic subject. The survey just outlined was based on the view that languages are comparable as systems. As long as we are looking for classes of words linguistically demarcated, we will have to exclude many languages from our list. (Moreover, we must expect our lists to be far from complete, because our decisions will have to be made for the most part on the basis of the descriptive work already done by others. With respect to these words, field techniques and analytical predilections greatly influence the linguistic description which an investigator ends up with. For example, in an otherwise detailed analysis of Ngbaka, a language spoken in the Central African Republic, there is practically no recognition of the 
importance of ideophonic adverbs in the language. The only place one sees any reference to them is under the discussion of reduplication as a morphological process. $)^{10}$

Our immediate task, it seems to me, is to establish some kind of diagnostic guide to the study of expressive phenomena. Its ultimate utility would be in comparing languages both synchronically and diachronically. It would also, of course, serve as a check-list for language investigators who would thereby avoid the error that was committed in describing the Ngbaka language. If, for example, we observe a considerable amount of reduplication in a language, we should ask ourselves questions like 'To what extent is there sound symbolism in these words?' and 'Are these reduplicated words considered by the speakers to be as legitimate a part of the language as all other words?'11 Other questions may be suggested by the following topics:

1. Phonology: onomatopoeia, alliteration, sound symbolism, reduplication, marginal phonological features, rhyming, punning, submorphemic segments (like $f$ - and $s l$-in English), etc.

2. Semantics: words characterized by restricted semantic domain, sensual (as opposed to cognitive) reference, extreme specificity of meaning (with little or no generic branching?), etc.

3. Ethnography: the community's attitude toward the words, characteristic channels of communication, etc.

4. Esthetics: emotionally heightened discourse.

5. Special types of discourse: secret languages, child language, magical incantations, artistic language, etc.

The use of this list, undoubtedly incomplete and inadequately categorized, can now be illustrated by looking at diverse phenomena in some languages. English, for example, has many ideophonic words, but they differ considerably from comparable words in African languages. ${ }^{12}$ Although many of them are reduplicative, they are not restricted to a single class of words (e.g. hanky panky n., flim flam n./v., hocus pocus n./v., itty bitty, itsy bitsy adj., kerflooey adv.), nor are they generally characteristic of anything more formal than what Martin Joos calls casual style. In English, moreover, we do not find large numbers of these words in fine semantic opposition within a set as we do in Gbeya.

Proceeding on the assumption that similar phenomena will be found in other languages, we are not surprised to learn that the Yokuts 'do' verbs occur in myths, but only rarely and only where the "implication of startling and ludicrous extravagance is appropriate" (Newman 1964: 375). In only one dialect are these verbs fully productive, but even here 
they are regarded as the linguistic property of children (375). Newman's description of the field experience is worth quoting: "I did not become aware of this class of verbs until, after two or three weeks of field work, I overheard some remarks which my informant's eight-year-old son was addressing to himself. Only with the greatest difficulty could I coax my informant to explain the 'do' verb which his child had used and to give me further examples of this class. It was evident that he regarded words of this type as being too silly for serious discussion and totally out of keeping with the essential sobriety of adulthood. Not until some time later did he tell me that these words were used primarily by children. But even after he had overcome his reluctance to discuss the 'do' verbs, he was never able to treat them seriously" (375). Although Newman may have inferred too much from the behavior of a single informant, it is clear that as a class of words available to the speaker of Yauelmani Yokuts 'do' verbs are very restricted in use and the attitude of the native speaker to them is decidedly different from what the rest of the language is favored with. (For Chinook see Boas 1911:627-33.)

Africans themselves have equated ideophonic words with English 'slang'. In other instances field workers have reported that the general reaction to their investigation of the use and meaning of these words was one of amusement. ${ }^{13}$

Furthermore, the phonological devices used in Ethiopian argots to disguise speech are remarkably similar to those we see in our ideophonic words (Leslau 1964). And in the magical phrases of the Trobriand Islanders, according to Malinowski (1922), "... a word will often be used in a shape quite different from those in which it is used in ordinary speech; that it will show notable changes in form and sound. Such phonetic peculiarities are most conspicuous in the main words, that is in the key-words and initial words. They are sometimes truncated, more often provided with additions, such as symmetrical or antithetic affixes; formatives added for the sake of sound. By these means there are produced effects of rhythm, alliteration and rhyme, often heightened and accentuated by actual vocal accent" (452); "Phonetically the most outstanding trait [of the final part of a spell, the dogina] is the purely onomatopoetic sound complexes, such as sididi or saidididi, or the three words sididi, tatata, numsa, found in the Kadumivala spell" (446).

In all of these forms of speech there is an esthetic element, if we use the term esthetic to designate "the property of speech forms to attract attention primarily to themselves rather than to the message they convey" (Garvin and Mathiot 1960:787). Defined in this way esthetics must 
consider all phonetic play (defined, for example, as "shaping words of lively connotation by imputing certain connotations to particular phonemes or sequences of phonemes" [Martin 1962:177]), linguistic play (defined, for example, as "methods of modifying the normal patterns of speech for purposes of entertainment or concealment" [Conklin 1964: 295]), and sound symbolism.

Up to this point we have been concentrating upon the phonological aspects of expressive speech. We must also consider the semantic aspects, for there is a strong correlation between certain patterns of phonetic play and the meanings they convey. We have already seen that the references of African ideophones seem to be fundamentally, if not exclusively, sensual. In some languages they are intensive. In Gbeya, for example, ideophones are mutually exclusive in the same clause with any other expression meaning 'very' (e.g. $d \hat{\varepsilon}$ 'very', $n \varepsilon \varepsilon^{\prime}$ saa nắ 'no fun'; fara tũj $d \hat{\varepsilon}$ or fara tũò $n \varepsilon \tilde{z}^{\text {saa }}$ nấ 'it is very dark' [as in speaking of a dark room] and fara tũò kóróró where kóróró is an ideophone). Where one finds words in other languages which by form and distribution resemble ideophones, one also finds that their meanings will seem to be expressive in nature.

In Semitic languages, for example, there is a widespread use of what Wolf Leslau (1961) calls 'echo-words'. In Ethiopic languages, for which 179 examples are cited (Amharic, 76; Tigrinya, 66; Tigre, 37), the words are often sensual (e.g. qäyyah mäyyoh 'multicolored objects in which red is dominant'), but the meanings are often pejorative and uncomplimentary (e.g. fandas gandas '(fall down) clumsily, lie down to sleep or sit in a careless manner', kuri muri 'nonsense, unintelligible talk'. A further significant fact about these echo-words is that so many of them can only follow the verbs 'to say' and 'to make', even though these meanings are absent from the meaning of the whole constructions: e.g. zäl mänzäl (alä) 'be clumsy in his walk, be plump, be rude', wälä zäläm (alä) 'act clumsily, awkwardly', sab rägäbb (alä) 'contract and expand', where alä is the verb. This feature is comparable to the use of go in English (e.g. it went kerflooey) or a verb in African languages which is either defective in some way or has the meaning 'to say'.

In some Indic languages, as in Bengali, words derived by certain patterns of reduplication are translated as 'specified noun and such', but convey various connotations some of which are sometimes jocular and sometimes demeaning. Thus, /boi/ 'book' produces /boitoi, boiphoi, boimoi/ 'books and such' and /buro/ 'old' produces /buroturo, burophuro, buromuro, burosuro/ 'old man and such', whose renderings are 
considered inadequate by a Bengalese linguist (Chatterjee 1962:134). The "subtle differences" he alludes to are probably affective and emotional ones. Some of the Assamese echo-words can also be translated ' $\mathrm{X}$ and such', but it appears that more than that is implied, although it is difficult with the amount of data available to me now to be more precise. ${ }^{14}$ For example:

mas tas 'fish and other food' (mas 'fish') saul taul 'rice and other edibles' (saul 'uncooked rice') ulta pulta 'mixed up, disorderly' (ulta 'backwards, upside down')

habi jabi 'garbage, messy growth' (habi 'jungle')

hen ten 'chatter'

$h \varepsilon \eta b \varepsilon \eta$ 'loud, quarrelsome, or shrill chatter'

owli bowli 'half asleep, unwashed, untidy appearance'

For other such examples - namely, in Bhojpuri - see Tiwary 1968.

\section{IMPLICATIONS FOR GENERAL LINGUISTICS}

What I hope to have accomplished to this point is to have demonstrated the wide distribution of certain linguistic phenomena having similar semantic and expressive functions, thereby contributing to a more comprehensive comparison of language systems.

We now ought to be better prepared, and willing, to take up several matters which have benefited far too little from cross-linguistic studies.

We can also consider individual creativity on the part of people with different linguistic systems. Since our language and our literary traditions are different from those of the Gbeya, in what ways can artistic creativity be compared? Can we say that with English a person must have the ability to extend the uses of words and make ingenious allusions whereas in Gbeya all that one can do is stretch the use of ideophones in original ways? Some would claim even more liberty than this for the African, even as Rabel did for the Khasi, for it is said that ideophones can be made on the spur of the moment and that the mark of a truly gifted storyteller is his ability to create ideophones just when they are most needed. If ideophonic neologisms could be documented, if we had better evidence than the statements of informants, we would have a striking phenomenon in language. But I have challenged these reports elsewhere and have already suggested the research that is needed. We need to start with the 
fact that the number of ideophones is incredibly high. If there were 2,600 in one Zulu dictionary, I should imagine that the language had 5,000 or more of these words. A study of Zulu artistry would then be an examination of a person's choice and use, but prior to this study there must be a determination of the precision with which these ideophones are in opposition. The bearing of all of this to the study of individual personality should be obvious. ${ }^{15}$

Closely related to the preceding topic is the investigation of what may for the moment be called 'semantic weight', which is really a measure of redundancy in language. We should like to know, for example, how much information - that is, denotative information, not connotative nor expressive - is carried by ideophones. If a language had 5,000 ideophones covering a limited range of semantic references, we might expect them to be heavily laden with information, especially if they were syntactically and lexically free; that is, not bound in occurrence to some other word. A language with 5,000 different but bound ideophones would be an extremely inefficient one, and one would expect that in time something would happen to the system, that, for example, many of these words would be lost. Information about this subject is available right on the African continent, for although the presence of ideophones is universal, their function appears to be highly disparate. Thus, Wolof appears to be very different from Gbeya. In my own attempt to collect ideophones in Wolof, I had very little success. Whereas I could easily get ideophones for the ten concepts being experimented with (whiteness, roundness, heaviness, etc.), I always got the same ones from about 100 individuals. This difference between Gbeya and Wolof is reinforced by the additional fact that in Wolof ideophones seem to be satellites of specific verbs. Thus, tol goes only with oyof 'be light in weight': oyof tol 'very light in weight'; tal goes only with $w \varepsilon \varepsilon x$ 'be very white', etc. (This is, of course, similar to the pattern reported for Crioulo, which is not surprising, since some of Crioulo's coterritorial languages are West Atlantic, to which family Wolof belongs.) In other words, the study of African ideophones should contribute to our understanding of how the shifting around of semantic loads is correlated with structural changes in languages that are demonstrably related.

University of Toronto 


\section{NOTES}

1 Walker (1965:266), using distinctions made by Brown (1958:307), defines expressive meaning in similar terms: "Expressive meaning is definable as that part of meaning which serves to categorize the speaker; it is often communicated by signals which the speaker does not control, or of which he is for the most part unaware."

When I say 'convey information', I do not mean to suggest any specification of the degree of consciousness in the encoding of the message. It is enough to say that the hearer of the discourse obtains information of a certain kind. It is information, because it is not accidental.

2 It will be made clear below why the words from the other languages are compared with African ideophones.

3 Care must be exercised in distinguishing this word from IDIOPHONE, which refers to a class of musical instruments. Doke's IDEOPHONE, which the spelling makes clear, includes the combining form of the word IDEA.

4 The writer, however, is engaged in research that is concerned with this problem. The field research is described in Samarin 1969, the analysis in Samarin 1974, and some of the initial conclusions in 1967, 1971, and 1972.

5 For example, languages might be classified according to the part of speech that the ideophones are found in, by the size of the ideophonic lexicon, by derivational processes (from verbs, etc.), by their distribution in sentences (i.e. their syntax), by the amount of information they contribute to a sentence, etc.

- Compare the ADOPTION of ideophones by these creoles with their Loss in the speech of urbanized (detribalized) Africans and in the indigenous African pidgins and creoles. There are few in Sango, practically none in Kituba. (Information about Kituba comes from Donald Deer, personal communication.)

7 We would welcome observations in spite of the difficulty of verifying their accuracy, for all observations constitute data. Out of a set of impressions and feelings about how words are used and what their connotations appear to be might come significant contributions to a sociolinguistic or psycholinguistic understanding of expressive speech. Therefore, we should record the observation of one field worker who reports that echo-words in Assamese seem to be used by women and children more than men, that they are characteristic of colloquial speech, that they can be expected to occur in humorous stories. She admits that because of her sex, she had more dealings with Assamese women and children than with men, but the feeling remains strong that men use echo-words less than the other groups.

8 I am indebted to H. Allan Gleason, Jr. for the Tamil reference.

9 That is, classes of words whose selection is frequently correlated with expressive as well as referential meaning. It would be possible to admit the existence of such a class even though some of its members were associated with more prosaic speech. That there are frozen or dead metaphors, for example, does not require rejecting all metaphors.

10 See Jacqueline Thomas 1963 and review by W. Samarin, Journal of African Languages 1965.

11 For a valuable contribution to the cross-linguistic function of reduplication see Harold Key 1965.

12 Others have called attention to them in one connection or another. Smithers (1954:194), for example, uses the concept of ideophony to explain some anomalous forms in English. Thus: "It should be clear that wrabbe, wrobbe and wragge are synonymous variants; that the double consonants of wrabbe, wrobbe, at least, are of expressive origin (as we learn from $-b$ - attested in vravla); that wrabbe, wrobbe exhibit the ideophonic apophony; and that all three words are ideophones". See also Thun 1963. 
13 It is significant also that non-African speakers of African languages, even those who have shown a very high proficiency in both understanding and speaking, very frequently fail to appreciate the importance of ideophones in these languages. Some even seem to be completely unaware of them. It would be enlightening to attempt an explanation of this failure in mastering another linguistic structure. It is not enough to suggest that a foreigner pidginizes the target language because of his concern with referential meaning. If it could be demonstrated that the meanings carried by ideophones were in some measure redundant, their omission would be understandable. But in at least some languages, their contribution to the total meaning of a sentence is important. In Xhosa, for example, one can make ideophonic equivalents of normal sentences. That is, an ideophonic utterance can summarize a DISCURSIVE one. It is tempting to suggest that the learner filters out the ideophones because of the incommensurability of his own expressive system with that of the other society. This hypothesis finds substantiation in the view that most efficient language learning (I am speaking of a hearing-speaking mastery) is correlated with empathy with the other party.

14 Information from Grace Jolly, personal communication.

15 Compare the statement made by Rulon Wells about the importance of the study of the playful uses of language (Wells and Keyser 1961 : xi-xii).

\section{REFERENCES}

Arden, A. H. 1954. A progressive grammar of common Tamil. 5th ed., 2nd impression; revised by A. C. Clayton. Madras: The Christian Literature Society.

Banker, Elizabeth M. 1964. Bahnar reduplication. The Linguistic Circle of Saigon and the Summer Institute of Linguistics, Mon-Khmer Studies I, 119-34.

Bernard-Thierry, Solange. 1961. Les onomatopées en Malgache. Bulletin de la Société de Linguistique de Paris, 51(1).240-69.

Boas, Franz. 1911. Chinook. Handbook of American Indian languages, Bureau of American Ethnology, Bulletin 40, Pt. I, 559-665.

Brown, Roger. 1958. Words and things. Glencoe, Ill.: Free Press.

Conklin, Harold C. 1964. Linguistic play in its cultural context. Language in culture and society, ed. by Dell Hymes, 295-300. New York, Evanston and London: Harper and Row. (Originally published in 1959).

Doke, Clement M. 1935. Bantu linguistic terminology, London: Longmans, Green and $\mathrm{Co}$.

Doke, C. M., and Vilakazi, B. W. 1958. Zulu-English dictionary. 2nd ed. revised with addendum. Johannesburg: Witwatersrand University Press.

Fivaz, Derek. 1963. Some aspects of the ideophone in Zulu (Hartford Seminary Foundation, M.A. Thesis). Hartford Seminary Foundation: Hartford Studies in Linguistics, No. 4.

Garvin, Paul L., and Madeleine Mathiot. 1960. The urbanization of the Guarani language - a problem in language and culture. Men and cultures: Selected papers of the Fifth International Congress of Anthropological and Ethnological Sciences (1956), ed. by Anthony F. C. Wallace. Philadelphia: University of Pennsylvania Press.

Green, Margaret M., and Igwe, G. E. 1963. A descriptive grammar of Igbo. London: Oxford University Press.

Householder, F. W., Jr. 1962. Azerbaijani onomatopes. American Studies in Altaic Linguistics 13.115-21. 
Key, Harold. 1965. Some semantic functions of reduplication in various languages. Anthropological Linguistics 7(3).88-102.

Leslau, Wolf. 1961. Echo-words in Ethiopic. Annales d'Ethiopie 4.205-38.

-. 1964. Ethiopian Argots. The Hague: Mouton.

Malinowski, B. 1922. Argonauts of the Western Pacific. London: G. Routledge and Sons.

Martin, Samuel E. 1962. Phonetic symbolism in Korean. American Studies in Altaic Linguistics 13.177-89.

Miller, John D. 1964. Word classes in Brou. The Linguistic Circle of Saigon and the Summer of Institute of Linguistics, Mon-Khmer Studies I, 41-62.

Newman, Stanley S. 1964. Linguistic aspects of Yokuts style. Language in Culture and Society, ed. by Dell Hymes, 372-77. New York, Evanston and London: Harper and Row. (Originally published in 1940.)

Nida, Eugene A. 1964. Toward a science of translating. Leiden: E. J. Brill.

Rabel, Lili. 1961. Khasi, a Language of Assam. Baton Rouge: Louisiana State University Press.

Samarin, William J. 1965a. Perspective on African ideophones. African Studies 24.11721.

-. 1965b. The Gbeya language: Grammar, texts, and vocabularies. Berkeley and Los Angeles: University of California Press.

-. 1965c. Review of Thomas 1963. Journal of African Languages 4.231-34.

-. 1967a. A grammar of Sango. The Hague: Mouton.

-. 1967b. Determining the meanings of ideophones, Journal of West African Languages 4.35-41.

-. 1969. The art of Gbeya insults. International Journal of American Linguistics 35.323-29.

- 1970. Field procedures in ideophone research. Journal of African Languages 9.27-30.

- 1971a. Salient and substantive pidginization. Pidginization and Creolization of Languages, ed. by Dell Hymes, 117-40. Cambridge: Cambridge University Press.

- 1971b. Measuring variation in the use of Gbeya ideophones. Actes du 8ème Congress de la Société Linguistique de l'Afrique Occidentale (Annales de l'Université d'Abidjan, Série H, Fascicule hors série), 2.483-88.

-. 1971c. Survey of Bantu ideophones. African Language Studies 12.130-68.

-. 1972. Appropriateness and metaphor in the use of ideophones. Orbis 20.356-69.

- 1974. Semantics without native intuition. Les langues sans tradition écrite: Méthodes d'enquête et de description. Actes du Colloque International du CNRS (1971). Paris: Société d'Études Linguistiques et Anthropologiques de France, Nu. 3. Pp. 159-74.

- 1975 Theory of order with disorderly data. Linguistics and anthropology: In honor of C.F. Voegelin, ed. by M. Dale Kinkade, Kenneth L. Hale and Oswald Werner, 509-19. Lisse: Peter de Ridder.

-. In press. Linguistic adaptation to speech functions. Language in anthropology. Vol. 3: Language evolution, ed. by William McCormack. The Hague: Mouton.

-. In press. Simplification, pidginization and language change. Readings in Creole studies, ed. by Morris Goodman, Ian F. Hancock, Bernd Heine, and Edgar Polomé.

Sapir, Edward. 1951. A study in phonetic symbolism. Selected Writings of Edward Sapir, ed. by David G. Mandelbaum, 61-72. Berkeley and Los Angeles: University of California Press. (Originally published in 1929).

Smalley, William A. 1961. Outline of Khmu? Structure. American Oriental Series, Essay No. 2. New Haven: American Oriental Society. 
Stewart, William A. 1962. Creole languages in the Caribbean. Study of the Role of Second Languages in Asia, Africa, and Latin America, ed. by Frank A. Rice, 34-53. Washington, D.C.: Center for Applied Linguistics.

Thomas, Jacqueline. 1963. Le parler Ngbaka de Bokanga. The Hague: Mouton.

Thun, Nils. 1963. Reduplicative Words in English (A study of formations of the types tick-tick, hurly-burly and shilly-shally). Uppsala: University Academy.

Tiwary, K. M. 1968. The echo-word construction in Bhojpuri. Anthropological Linguistics 10(4).32-38.

Walker, Willard. 1965. Taxonomic structure and the pursuit of meaning. Southwestern Journal of Anthropology 21.265-75.

Watson, Richard. 1966. Reduplication in Pacoh. Hartford Seminary Foundation, M.A. Thesis.

Wells, Rulon, and Keyser, Jay. 1961. The common feature method. New Haven: Yale University Press.

Williamson, Kay. 1965. Ideophones in Ijo. Paper read at the Fifth West African Languages Survey Congress, University of Ghana, April 5-9.

Wilson, W. André A. 1962. The Crioulo of Guine. Johannesburg: Witwatersrand University Press. 
